\title{
Bio-Mediated Sandy Soil Stabilization Using Urease Enzymatic Calcite Precipitation: A Sustainable Solution
}

\author{
${ }^{1}$ V Srinivasa Reddy, ${ }^{2}$ K Hema Latha, ${ }^{3}$ Ravulaparthi Sudha Lahari, ${ }^{4} M$ V Seshagiri Rao \\ ${ }^{1}$ Professor of Civil Engineering, GRIET, Hyderabad, India. \\ ${ }^{2}$ Assistant Professor of Civil Engineering, GRIET, Hyderabad, India. \\ ${ }^{3}$ M.Tech (Structural Engineering), Department of Civil Engineering, GRIET, Hyderabad, India. \\ ${ }^{4}$ Professor of Civil Engineering, CVR College of Engineering, Hyderabad, India.
}

\begin{abstract}
A recently developing bacteria based soil-stabilization technique inspired from microbially impelled calcite precipitation phenomena is verified for geo-technical applications. This phenomena make use of the metabolic mechanics of microorganisms to produce calcite precipitation all through soil matrix enhancing the soil's engineering properties. Unconfined compressive strength (UCS) and soil hydraulic conductivity or permeability is evaluated to validate the formation of mineral precipitates between and around soil grains. Due to metabolic process of bacteria calcite minerals are generated binding the soil particles together reducing the voids volume and diameter subsequently a dense microstructure is formed. This improvement of soil homogeneity reduces the hydraulic conductivity and increase the unconfined compression strength of bacteria-treated soil samples. From the results of experimental investigations it is confirmed that mineral precipitation biologically proves to be an effective and efficient method of soil stabilization in increasing the stiffness and permeability of soil samples considered for study.
\end{abstract}

\section{Introduction}

In the present study the two soil samples with fine and coarse particle size distribution were treated with Sporosarcina pasteurii bacteria to stimulate mineral precipitation by producing urease enzyme which catalyzes the urea hydrolysis forming $\mathrm{CO}_{2}$ and $\mathrm{NH}_{3}$. Due to high $\mathrm{pH}$ environment of produced ammonia, the soil matrix nearby converts to extremely alkaline and calcium ion from calcium nutrient source reacts with $\mathrm{CO}_{2}$ to form calcium carbonate minerals which will ultimately binds the soil particles.

\section{MICP Mechanism}

Biological methodology for soil consolidation is a comparatively novel practise, so it is essential to collect further outcomes to mimic real situations before applying on a larger scale. In this study, bacteria- based consolidation method is developed by adding the microbial self-healing agent which is likely to improve the feature of density largely by bacteria prompted mineral precipitations (MICP). In the current study the designated spore-forming alkaliphilic calcite precipitating bacteria would decompose urea to $\mathrm{CO}_{3}{ }^{2-}$ which can react with $\mathrm{Ca}^{2+}$ to form $\mathrm{CaCO}_{3}$ in alkaline environment. The MICP mechanism is ascribed to urea hydrolysis by the urease enzyme of bacteria into $\mathrm{NH}_{3}$, and $\mathrm{CO}_{3}{ }^{-}$ions causing the formation of calcite minerals. So urease activity is responsible for the formation of crystal precipitates.

\section{Choice of bacterial strain and cultivation media}

For isolation, enrichment culture technique will be used to enrich calcite precipitating strains in Urea broth. After enrichment, distinct bacterial strains were obtained on Urea agar. Based on qualitative and quantitative screening for urease activity, an isolate possessing higher calcite formation and urease activities $(\mu \mathrm{mhos} / \mathrm{cm})$ is identified and selected for study. For enrichment, $1 \mathrm{ml}$ or one gram of bacterial strain is added to urea broth and incubated at $37^{\circ} \mathrm{C}$ for 48-72 h. After enrichment, the broth samples were serially diluted and plated on Urea agar $(\mathrm{pH} 9.4)$ containing urea $(20 \mathrm{~g} / \mathrm{l})$, sodium bicarbonate $(2.12 \mathrm{~g} / \mathrm{l})$, ammonia chloride (10 g/l), Nutrient broth $(3.0 \mathrm{~g} / \mathrm{l})$, calcium chloride hydrate $(25 \mathrm{~g} / \mathrm{l})$. Crystal precipitation in the form of colonies 
will be appeared and selected for further growth in urea based nutrient broth. Standard gram staining procedure can also be conducted to identify the bacterial strains growth and formation of endospores. The selection of the most suitable bacteria for MICP is mostly based on higher carbonate precipitation yield of the ureolytic pathway. A spore forming alkaliphilic bacteria is chosen based on $\mathrm{CaCO}_{3}$ precipitation yield. Bacterial decomposition of urea to produce mineralized calcium carbonate critically depends on urease activity.

\section{Molecular identification of the isolate}

The pure culture will be isolated and is kept continuously on nutrient agar slants. It forms irregular dry white colonies on nutrient agar plate. Whenever we require bacterial culture a single colony of strain is isolated and inoculated in a broth of nutrients and allowed to grow at a temperature of 37 degree celcius and on orbital shaker. 16S rRNA gene sequence analysis is carried out to get the dendrogram which depicts the hierarchical relations among the family of bacillus. The 16S RNA bacterial gene is sequenced and analysed for the feasibility to be used for the study.

\section{Identification of bacteria growth characteristics}

Bacteria selected is grown in different medium to understand the suitability of nutrients for optimum bacterial growth and subsequently calcite crystals. To assess the cell concentration an optical density test is conducted. Similarly serial dilution technique is used to find the cell count. Urease activity of the selected bacteria is tested in different medium of nutrients. Phenol-hypochlorite assay is conducted to determine the ammonia release concentration.

\section{Urease activity}

Quality of the urease activity of the bacteria can be found by inoculating the selected bacterial strain on urea agar tubes at 37 degree Celsius for 3 to 5 days. Tubes are checked every day so when colour changes to orange from red indicates superior urease activity of bacterial strain

Quantity of urease activity can be assessed using an electric conductivity test. Selected bacterial strain along with nutrients which has grown throughout the night is centrifuged to make cell pellets. These cell pellets are mixed with distilled water and urea nutient is added to check the optical density $\mathrm{OD}_{600}$ so that when the value of OD is 1 then conductivity test is carried out to determine cell concentration. The conductance of light is recorded regularly until the desired cell count is obtained.

\section{Bio-mineralization test}

To calculate the amount of calcite crystal precipitation pure bacterial culture is inoculated $n$ nutrients containing the urea and calcium chloride on agar tubes at suitable temperature for required days on the orbital shaker and centrifuged to make pellets out of it. These bacterial cell pellets are dried and weights are taken to quantify the dry calcite crystal precipitate.

Detection of calcium carbonate was also carried out using Fourier transform infrared spectroscopy (FTIR). The calcite mineral presence will be established by observing the curve peaks formed at $1000-1300 \mathrm{~cm}^{-1}$ wave number.

\section{Preparation of bacterial suspension}

Selected spore-forming alkaliphilic calcite precipitating bacteria is first cultured in solid media (agar) are then transferred to nutrient broth (liquid media) which is sterile and kept in shaking incubator (to ensure uniform growth) for about 48 hrs. From this we would get the mother culture of the bacteria. Later, it will be diluted by serial dilution technique for different cell concentrations, so that it can be utilized in soil samples. Concentration of cells is measured by Haemocytometer and optical density is found by spectrophotometer analysis before adding bacteria to soil sample.

Additionally Calcium lactate can be used as Ca supplement for metabolic activity

\section{Cell Concentrations}

Various bacterial cell count used are $10^{3}$ cells $/ \mathrm{ml}, 10^{4}$ cells $/ \mathrm{ml}, 10^{5}$ cells $/ \mathrm{ml}, 10^{6}$ cells $/ \mathrm{ml}$ and $10^{7}$ cells $/ \mathrm{ml}$.

\section{Nutrients Broth for cementation}

It comprised essentially urea, sodium bicarbonate, ammonia chloride, calcium chloride hydrate (25 g/l)

\section{Sand Samples}

Two types of sand samples (Coarse sand: $4.75 \mathrm{~mm}-2.00 \mathrm{~mm}$ IS Sieve and Fine sand: $0.425 \mathrm{~mm}-0.075 \mathrm{~mm}$ IS Sieve) having different particle size distribution are used in this study. Samples are made free from roots, organic matter etc. by sanitation and was then oven dried. Specific gravity of sand is determined by IS: 2720- 1985 (Part 3).

The geotechnical properties are evaluated as shown below-

Table 1. The geotechnical properties of sand

\begin{tabular}{|l|l|}
\hline & \\
\hline Liquid limit & Non-plastic \\
\hline Opt. moisture content & $16 \%$ \\
\hline Sp. gravity & 2.65 \\
\hline Maximum dry density & $13.9 \mathrm{kN} / \mathrm{m}^{3}$ \\
\hline
\end{tabular}




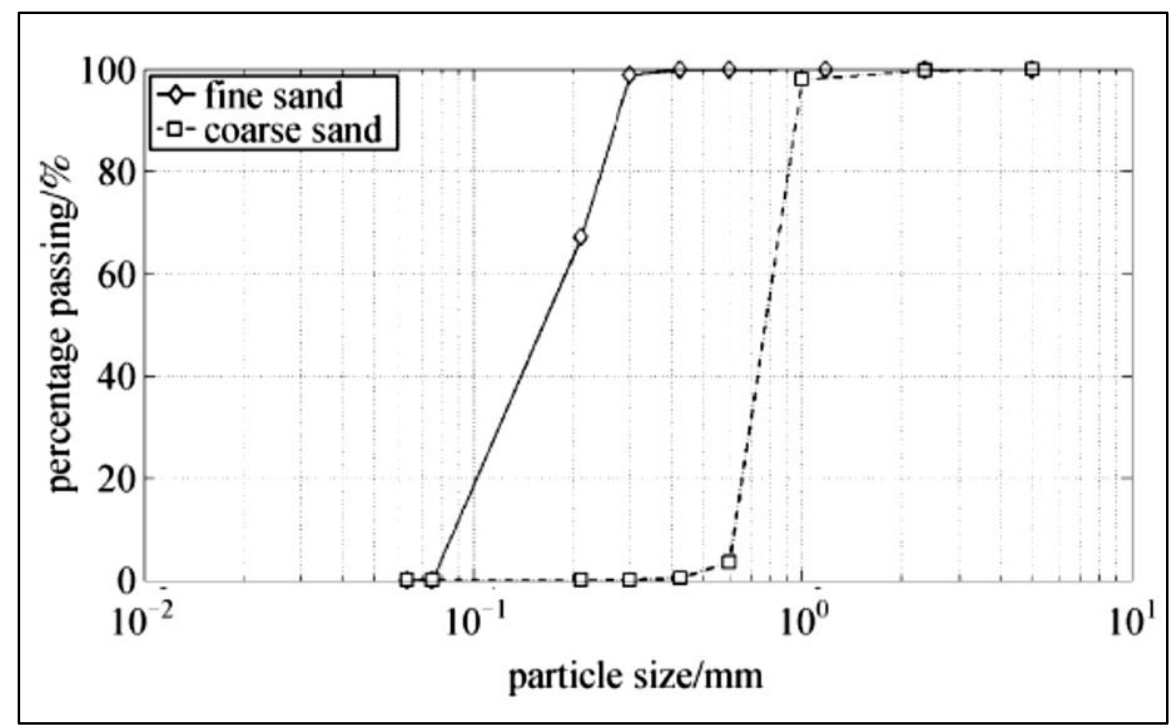

Fig. 1. Particle gradation Chart

\section{Grain size distribution analysis}

\subsection{Sieve Analysis}

Sieve analysis is carried out to assess the grain size distribution of sample as per IS: $2720-1985$ (Part 4). The sample is put through various sieves. $4.25 \mathrm{~mm}, 2 \mathrm{~mm}, 1 \mathrm{~mm}$, 425 micron, 150 micron and 75 micron. A graph is drawn with percentage passing of particles versus the sieve size. Sample retained on each sieve is weighed. If the sample passing $75 \mu \mathrm{m}$ is more than $10 \%$ then hydrometer method can be used to grade the particles size of sample

\subsection{Hydrometer analysis}

Based on the nomogram given in IS: 2720- 1985 (Part 4), the diameter of the grains for different hydrometer readings are obtained. With the results obtained from sieve analysis and hydrometer method analysis, semi-log graph between grain size on $\mathrm{x}$ axis (log scale) and the percentage finer than the stated diameter as $\mathrm{y}$ axis.

\subsection{Grade Curve}

Grading curve shows the grain size distribution of sample considered. $\mathrm{D}_{60}, \mathrm{D}_{30}$, and $\mathrm{D}_{10}$ corresponds to grain size at which $60 \%, 30 \%$ and $10 \%$ fines are available are obtained from the curve. The curve is plotted with percentages of fines and the grain size on on $\mathrm{y}$ and $\mathrm{x}$-axes respectively using data obtained from on the sieve analysis test completed on given samples. $\mathrm{D}_{10}$ is considered as the effective particle size which indicates the size of grains below which $10 \%$ particles by weight are finer and $90 \%$ particles are coarser than $\mathrm{D}_{10}$. Likewise, $\mathrm{D}_{60}$ is the size of the sand grain below which $40 \%$ of the sample has coarser grains and $60 \%$ of the sample has finer grains similarly with $\mathrm{D}_{30}$ represents the size of the sand grain below which $30 \%$ fine and $70 \%$ coarse sand grains are available. $\mathrm{D}_{10}, \mathrm{D}_{30}$ and $\mathrm{D}_{60}$ are assimilated from grade curve.

\subsection{Parameters for Gradation}

The uniformity-coefficient $\left(\mathrm{C}_{\mathrm{u}}\right)$ and the gradation coefficient $\left(\mathrm{C}_{\mathrm{c}}\right)$ are the indicators of gradation of any soil. These indicators aid to categorize the sample either as well or poorly graded. If $\mathrm{C}_{\mathrm{u}}$ is the range 4 to 6 then the sample is considered as well-graded. If $<4$, poor-graded and uniformgraded samle has value 1 . From the graph drawn between percentage of fines and grain size, the $\mathrm{D}_{10}, \mathrm{D}_{30}, \mathrm{D}_{60}, \mathrm{Cu}$ and $\mathrm{C}_{\mathrm{c}}$ values were find out from the plotted gradation curve. Uniformity and curvature coefficients are assesses using formulae-

$$
\begin{gathered}
\mathrm{C}_{\mathrm{u}}=\mathrm{D}_{60} / \mathrm{D}_{10} \\
\mathrm{C}_{\mathrm{c}}=\left(\mathrm{D}_{30}\right)^{2} / \mathrm{D}_{60} \times \mathrm{D}_{10}
\end{gathered}
$$

The uniformity-coefficient, curvature-coefficient and the effective size $\left(\mathrm{D}_{10}\right)$ describe a exact nature of sample. Upper value of $\mathrm{C}_{\mathrm{u}}$ shows that the soil sample contains grains with variable sizes. 
Table 2. Sieve Analysis data of the samples procured

\begin{tabular}{|c|c|c|c|c|c|c|c|c|}
\hline $\begin{array}{c}\text { Sand } \\
\text { Sample }\end{array}$ & $\begin{array}{c}\text { Grain size } \\
\text { between } 4.75 \\
\mathrm{~mm} \text { and } 2.00 \\
\mathrm{~mm} \\
\text { (\% by weight) }\end{array}$ & $\begin{array}{c}\text { Grain size } \\
\text { between } 2.00 \\
\mathrm{~mm} \\
\text { and } 0.425 \mathrm{~mm} \\
\text { (\% by weight) }\end{array}$ & $\begin{array}{c}\text { Grain size } \\
\text { between } \\
0.425 \mathrm{~mm} \\
\text { and } 0.075 \\
\mathrm{~mm} \\
\text { (\% by } \\
\text { weight) }\end{array}$ & $\begin{array}{c}\mathrm{D}_{10} \\
\text { (particle } \\
\text { size of } \\
\text { grains } \\
\text { in mm } \\
\text { below } \\
\text { that size } \\
10 \% \text { of } \\
\text { the } \\
\text { sample } \\
\text { are } \\
\text { finer } \\
\text { and } \\
90 \% \text { are } \\
\text { coarser) }\end{array}$ & $\begin{array}{c}\mathrm{D}_{30} \\
\text { (particle } \\
\text { size of } \\
\text { grains } \\
\text { in mm } \\
\text { below } \\
\text { that size } \\
30 \% \text { of } \\
\text { the } \\
\text { sample } \\
\text { are } \\
\text { finer } \\
\text { and } \\
70 \% \text { are } \\
\text { coarser) }\end{array}$ & $\begin{array}{c}\mathrm{D}_{60} \\
\text { (particle } \\
\text { size of } \\
\text { grains } \\
\text { in mm } \\
\text { below } \\
\text { that size } \\
60 \% \text { of } \\
\text { the } \\
\text { sample } \\
\text { are } \\
\text { finer } \\
\text { and } \\
30 \% \text { are } \\
\text { coarser) }\end{array}$ & $\begin{array}{l}\text { Uniformity } \\
\text { Coefficient } \\
\text { (Cu) }\end{array}$ & $\begin{array}{l}\text { Curvature } \\
\text { Coefficient } \\
\text { (Cc) }\end{array}$ \\
\hline $\begin{array}{c}\text { Coarse } \\
\text { Sand }\end{array}$ & 17 & 60 & 23 & 0.174 & 0.433 & 1.113 & 6.40 & 0.97 \\
\hline $\begin{array}{l}\text { Fine } \\
\text { sand }\end{array}$ & 5 & 40 & 55 & 0.078 & 0.194 & 0.482 & 6.12 & 1.00 \\
\hline
\end{tabular}

\section{Preparation of Sand Columns}

Preparation of coarse and fine sand column samples were made by the stuffing sand into poly-vinyl chloride (PVC) tubes of $180 \mathrm{~mm}$ height $\mathrm{x} 45 \mathrm{~mm}$ diameter. The dry densities is about $13.9 \mathrm{kN} / \mathrm{m}^{3}$ for sand samples. For permeability test, Sporosarcina pasteurii bacterium of different cell count suspended in nutrients were permitted to flow through samples and percolation method is used for unconfined compression strength.

\section{Permeability}

The permeability of coarse and fine sand samples were evaluated using constant head permeability test as per IS: 2720) - 1986(Part 17).

\section{Unconfined Compression Strength}

This test is conducted as per IS: 2710- 1986 (Part 10) to determine the shear capacity of the sand samples.

\section{Test Results and Discussions 16.1 Permeability}

The results for coefficient of permeability for coarse and fine sand samples when treated with various cell concentrations of Sporosarcina pasteurii bacterium establish that bacteriological treatment is very effective on coarse sand samples with mean grain size $\left(D_{50}\right)=0.984 \mathrm{~mm}$ than fine sand with mean grain size $\left(D_{50}\right)=0.242 \mathrm{~mm}$. This is very evident as coefficient of permeability of coarse sand is $3.61 \times 10^{-7} \mathrm{~cm} / \mathrm{s}$ which is less than that of fine sand whose value is $1.13 \times 10^{-6}$ at $10^{5}$ cell concentration of Sporosarcina pasteurii bacterium.

\subsection{Unconfined Compression Strength}

The outcomes for unconfined compression strength for coarse and fine sand samples when treated with various cell concentrations of Sporosarcina pasteurii bacterium establish that bacteriological treatment is very effective on coarse sand samples with mean grain size $\left(D_{50}\right)=0.984 \mathrm{~mm}$ than fine sand with mean grain size $\left(D_{50}\right)=0.242 \mathrm{~mm}$. This is very evident as un-confined compression strength of coarse sand is $3.14 \mathrm{MPa}$ which is more than that of fine sand whose value is $2.89 \mathrm{MPa}$ at $10^{5}$ cell concentration of Sporosarcina pasteurii bacterium. 
Table 3. Permeability of Untreated and Microbially Treated Samples

\begin{tabular}{|c|c|c|c|c|}
\hline \multirow[b]{2}{*}{ Sample } & \multirow[b]{2}{*}{$\mathrm{D}_{50}(\mathrm{~mm})$} & \multirow{2}{*}{$\begin{array}{l}\text { Cell Count } \\
\text { (cells per ml) }\end{array}$} & \multicolumn{2}{|c|}{ Coefficient of permeability $(\mathrm{cm} / \mathrm{sec})$} \\
\hline & & & Before Treatment & $\begin{array}{c}\text { After } \\
\text { Treatment }\end{array}$ \\
\hline \multirow{5}{*}{ Coarse Sand } & \multirow{5}{*}{0.984} & $10^{3}$ & $1.55 \times 10^{-2}$ & $0.31 \times 10^{-7}$ \\
\hline & & $10^{4}$ & $1.55 \times 10^{-2}$ & $0.50 \times 10^{-7}$ \\
\hline & & $10^{5}$ & $1.55 \times 10^{-2}$ & $0.61 \times 10^{-7}$ \\
\hline & & $10^{6}$ & $1.55 \times 10^{-2}$ & $0.45 \times 10^{-7}$ \\
\hline & & $10^{7}$ & $1.55 \times 10^{-2}$ & $0.44 \times 10^{-7}$ \\
\hline \multirow{5}{*}{ Fine Sand } & \multirow{5}{*}{0.242} & $10^{3}$ & $1.32 \times 10^{-3}$ & $0.56 \times 10^{-6}$ \\
\hline & & $10^{4}$ & $1.32 \times 10^{-3}$ & $0.82 \times 10^{-6}$ \\
\hline & & $10^{5}$ & $1.32 \times 10^{-3}$ & $1.13 \times 10^{-6}$ \\
\hline & & $10^{6}$ & $1.32 \times 10^{-3}$ & $0.78 \times 10^{-6}$ \\
\hline & & $10^{7}$ & $1.32 \times 10^{-3}$ & $0.55 \times 10^{-6}$ \\
\hline
\end{tabular}

From the permeability coefficients of samples treated with and without bacteria suggest that the coarse sand having size between $4.75 \mathrm{~mm}$ to $2.00 \mathrm{~mm}$ has less permeability than fine sand with size between $0.0425 \mathrm{~mm}$ and $0.0075 \mathrm{~mm}$. In fine sand, the high viscous bacterial suspension cannot pass through the sample so that effective bio-mineralization is prevented from happening due to restricted spaces between soil grains. The optimum cell concentration is chosen where permeability is very low and being which permeability increases due to turbid bacterial suspension. As concentration increases turbidity of bacterial solution also increases due to formation of suspended organic matter in the bacterial solution. This matter prevents the solution to seep through the sand matrix for the bio-mineralization mechanism to happen. So the bonds developed are very weak and structure has more pathways for permeability.

Table 4. Unconfined Compression Strength of Untreated and Sporosarcina pasteurii Treated sand Samples

\begin{tabular}{|c|c|c|c|c|}
\hline \multirow[b]{2}{*}{ Sample } & \multirow[b]{2}{*}{$\mathrm{D}_{50}(\mathrm{~mm})$} & \multirow{2}{*}{$\begin{array}{l}\text { Cell Count } \\
\text { (cells per } \mathrm{ml} \text { ) }\end{array}$} & \multicolumn{2}{|c|}{$\begin{array}{l}\text { Unconfined Compression Strength } \\
(\mathrm{MPa})\end{array}$} \\
\hline & & & $\begin{array}{l}\text { Distilled water } \\
\text { treated sample }\end{array}$ & $\begin{array}{c}\text { Bacteria }+ \text { nutrients } \\
+ \text { Calcium lactate } \\
\text { treated sample }\end{array}$ \\
\hline \multirow{5}{*}{ Coarse Sand } & \multirow{5}{*}{0.984} & $10^{3}$ & 1.39 & 1.76 \\
\hline & & $10^{4}$ & 1.39 & 2.81 \\
\hline & & $10^{5}$ & 1.39 & 3.14 \\
\hline & & $10^{6}$ & 1.39 & 2.43 \\
\hline & & $10^{7}$ & 1.39 & 1.99 \\
\hline \multirow{5}{*}{ Fine Sand } & \multirow{5}{*}{0.242} & $10^{3}$ & 2.31 & 2.64 \\
\hline & & $10^{4}$ & 2.31 & 2.77 \\
\hline & & $10^{5}$ & 2.31 & 2.89 \\
\hline & & $10^{6}$ & 2.31 & 2.56 \\
\hline & & $10^{7}$ & 2.31 & 2.44 \\
\hline
\end{tabular}

Unconfined compressive strength of sand samples treated with and without bacteria suggests that at optimum cell concentration compressive strengths are more. Unconfined compressive strength of coarse sand is $3.14 \mathrm{MPa}$ in coarse sand treated with bacteria where as in unconfined compressive strength in untreated coarse sand sample is 1.39 $\mathrm{MPa}$, So bacteria treated sand has stiffness nearly 2,3 times more than untreated sample. 


\section{Conclusions}

Bio-mediated sandy soil stabilization using urease enzymatic calcite precipitation is a sustainable solution to solidify sand using the mechanism of bio-mineralization. Test conducted to validate the strength and permeability of sand treated with bacteria revealed the following definite conclusions as presented below-

1. Permeability of coarse sand is significantly reduced than in fine sand after the corresponding samples are treated with nutrients suspended Sporosarcina pasteurii bacterial solution.

2. Unconfined Compression Strength of coarse sand is significantly high than that of fine sand after the corresponding samples are treated with nutrients suspended Sporosarcina pasteurii bacterial solution.

3. Calcite mineral precipitation due to bacteria is more in coarse sand than in fine sand due to better dispersion of bacterial solution in coarse sand matrix than in fine sand matrix leading to superior manifestation of bio-mineralization phenomena.

4. Calcium lactate is used to supplement the microbial activity and promote incessant urease enzymatic calcite precipitation.

5. Optimum cell concentration of Sporosarcina pasteurii bacteria solution is required for stimulating urease activity and for maximum mineral precipitation. Insufficient cell concentration hinders the sufficient calcite mineral precipitation in sand matrix.

6. More than acceptable cell concentration inhibits the growth of bacteria resulting from an alkaline environment produced by urea hydrolysis and also high cell concentration increases the turbidity of the bacterial solution may deter its entry into the sand matrix due to which complete mineral precipitation did not take place and also the dispersion of mineral precipitates in sand matrix is not uniform.

\section{References}

1. Cheng, L., Shahin, M.A. and Mujah, D., 2017. Influence of key environmental conditions on microbially induced cementation for soil stabilization. Journal of Geotechnical and Geoenvironmental Engineering, 143(1), p.04016083.

2. Mujah, D., Shahin, M.A. and Cheng, L., 2017. State-of-the-art review of biocementation by microbially induced calcite precipitation (MICP) for soil stabilization. Geomicrobiology Journal, 34(6), pp.524-537.

3. Forster, S.M., 1990. The role of microorganisms in aggregate formation and soil stabilization: types of aggregation. Arid Land Research and Management, 4(2), pp.85-98.

4. Rajagiri A, MN Sandhya, Nawaz S, Suresh Kumar T, E3S Web of Conferences 8701004 (2019)

5. Bibi, S., Oualha, M., Ashfaq, M.Y., Suleiman, M.T. and Zouari, N., 2018. Isolation, differentiation and biodiversity of ureolytic bacteria of Qatari soil and their potential in microbially induced calcite precipitation (MICP) for soil stabilization. RSC advances, 8(11), pp.5854-5863.

6. Tummala Suresh Kumar, Kosaraju Satyanarayana, Materials Today: Proceeding, 26 (2), 3228-3233, (2020).

7. Harris, R.F., Chesters, G., Allen, O.N. and Attoe, O.J., 1964. Mechanisms involved in soil aggregate stabilization by fungi and bacteria. Soil Science Society of America Journal, 28(4), pp.529-532. 